\title{
Transaction Cost and Market Development of Cassava Production in Jember Regency, East Java, Indonesia
}

\author{
M. Abd. Nasir ${ }^{1 *}$, Ciplis Gema Qori'ah ${ }^{1}$ \\ ${ }^{* 1}$ Faculty of Economics and Busines - University of Jember
}

\begin{abstract}
Rapidly growing food needs require a strategy to achieve self-sufficiency based on a diversity of local food resources. One source of carbohydrates based on local ingredients, namely cassava, which occupies a quite important role in the food structure of Indonesian society, after rice and corn. Institutional arrangement and transaction costs in managing cassava production in Jember Regency, East Java, Indonesia have strong implications in relation to specifications and estimates of production function responses. If transaction costs are fixed costs, discontinuities will occur in response to incentives that occur in the market. The purpose of this study is to determine the amount of transaction costs and the development of cassava markets that occur in the business of managing cassava production in Jember Regency. The method used in answering the purpose of the study is value chain analysis. Based on the results of the analysis it was found that the largest transaction costs were at the level of sellers and industry compared between farmers and sellers. At the farmer level, social capital is one of the strengths for cassava marketing sustainability. The social capital is in the form of guarantees for the certainty of the sale of crops by buyers who already have a cooperative relationship. The policy recommendations that can be given are the optimization of the role of farmer groups for the sustainability of cassava production and the implementation of cassava-based processed product development programs and the provision of marketing.
\end{abstract}

Keyword: Transaction Costs, Market Development, Cassava

\section{Introduction}

Food needs that are growing rapidly require strategies to achieve self-sufficiency based on the diversity of local food resources (indegenous resources). One source of carbohydrates based on local ingredients is cassava which plays an important role in the food structure of Indonesian society, after rice and corn [1] [2]. Aside from being a food carbohydrate can also be used as feed ingredients and industrial raw materials. Therefore the development of cassava is very important in the effort to supply non-rice carbohydrate food, diversification / diversification of local food consumption, the development of the processing industry and agroindustry and as a source of foreign exchange through exports and efforts to support increased food security and food independence [3]. Cassava is agronomically able to adapt to the marginal environment so that it can be a good resource for development in areas dominated by marginal land and dry climate [4]. This, of course, will equalize development in marginal areas. On the other hand, cassava demand continues to increase both for consumption, feed and processed industries (cassava, chips, tapioca and cassava flour) and new renewable energy materials.

Jember Regency has various potential commodities in the agriculture sector, one of which is cassava. This is evident from the productivity and the amount of cassava production in Jember which is quite high. Based on data from the Central Statistics Agency of Jember Regency it is known that the productivity and amount of cassava production in 2012 were $174.40 \mathrm{kw} / \mathrm{ha}$ and $478,030 \mathrm{kw}$ with a total harvest area of 2,471 ha [5]. Potential distribution of cassava in Jember is quite evenly distributed, i.e. there are in 28 sub-districts of 31 subdistricts in the district, including: Kencong, Gumukmas, Puger, Wuluhan, Ambul, Tempurejo, Silo, Mayang, Mumbulsari, Ajung, Rambipuji, Balung, Semboro subdistricts. , Jombang, Sumberbaru, Tanggul, Bangsalsari, Panti, Sukorambi, Arjasa, Pakusari, Kalisat, Ledokombo, Sumberjambe, Sukowono, Jelbuk, Kaliwates, Sumbersari and Patrang [5].

Institutionalization is an important factor that drives the performance of the management of agricultural resources, especially cassava. Institutions produce regulations or policies which are the rules of the game in resource management [6] [7]. Each party has different roles and activities in managing agricultural resources. Conflicts between farmers and high transaction costs that tend to be inefficient are problems faced by agricultural entrepreneurs in the agricultural sector. The amount of transaction costs determined unilaterally by the buyer is unknown to the farmer resulting in an imperfect market. Thus the price received by farmers is cheaper than if

\footnotetext{
Corresponding author: abd.nasir@unej.ac.id
} 
farmers sell themselves. The implication of transaction costs is a problem that influences industry decisions on production, labor allocation and consumption decisions [8][9]. Increased transaction costs cause market failure. Institutional changes and transaction costs in managing cassava production in Jember have strong implications in relation to the specifications and estimates of the response of the production function. If transaction costs are fixed costs, discontinuities will occur in response to incentives that occur in the market [10][11]. So the purpose of this study is to determine the amount of transaction costs and the development of cassava markets that occur in the management of cassava production in Jember Regency. The Novelty of the research is the measurement of transaction costs from upstream to downstream using value chain analysis tools, so that from this result we will find who the most important role is in determining the price of cassava and the magnitude of the value added in the cassava market in each actor playing.

\section{LITERATURE REVIEW}

Transaction costs are a concept within the scope of institutional economics. Transaction costs are simply costs incurred and incurred to produce a transaction. Transaction fees are costs that come out before the transaction is made [12] [13] . In addition, transaction costs also refer to various costs that do not have a direct relationship with the transactions carried out. In practice, transaction costs can be in various formations. Transaction costs are a phenomenon that cannot be explained in classical economic flow [6]. Transaction costs are a different concept to transportation costs or distribution costs.

One of the studies examined in the cassava institution in Jember Regency is the existence and magnitude of transaction costs. Researchers tried to dig up information from respondents related to various kinds of costs incurred during the marketing process. Transaction costs do often arise when the process of marketing an item into the market. Observation results show that all respondents stated that transaction costs in the cassava marketing process at the farm level did not exist.

\section{RESEARCH METHODOLOGY}

Primary data is used to answer the research objectives. The research used purposive random sampling to determine of smaples. The samples used are cassava farmers (20 persons), traders (10 persons), industry (5 industry), until the end consumers (10 persons) of cassava in Jember Regency. Examining a business chain on the development of a product is the most important thing in maintaining the sustainability of production, in addition to getting detailed information about the added value generated in each business chain. The business chain can be approached with a value chain method (value chain) which is an instrument of economic development oriented to participatory methods and active actions aimed at supporting the growth of small and weak economic groups (Amarender, 2013). Value chains are arranged in concrete steps that are systematic, can be applied by local governments, the private sector and the community to be further applied in their respective regions in accordance with the problems faced and the final achievements expected. Each business actor has its own role and function in the cassava commodity value chain. The quality and quantity of production results is influenced by how much the business actors contribute according to their respective roles. Therefore, each business actor is closely related to other business actors in supporting aspects of product distribution continuity.

\section{RESULT AND DISCUSSION}

Cassava trading chain and its derivative products in Jember Regency are shown in figure 1. Farmers are functionally divided into two types of production activities, namely pure farmers and industrial farmers. Pure farmers are farmers who produce cassava and directly sell it without processing their harvest. Cassava yields from pure farmers are sold to traders of industrial farmers. Cassava farmers who still survive planting cassava are farmers who own fields and tend to be quite far from irrigation channels. The reason for growing cassava on the land is because cassava plants are relatively more adaptable in dry and rain-fed lands than other productive plants such as corn and chili. The pattern of planting cassava farmers in the highlands is to grow cassava for a year, starting in the middle of the rainy season and during the month of Ramadan and harvested during the month of Ramadan as well. The aim is to sell cassava crops to the tape making industry and it is predicted that post-harvest cassava prices will be more profitable as Ramadan approaches. The price stability is more due to the tape industry's need for cassava raw materials because the demand for tape tends to increase during Ramadan and Eid.

Cassava crop trading by pure farmers is carried out with several other economic actors, namely industrial farmers, traders, and small industries. Cassava prices at the level of pure farmers basically fluctuate in the range of Rp 700-2500/ kg. The price in this study based on the results of the interview showed an average price of $\mathrm{Rp} 1,500$ / kg. The payment system that applies in Jember Regency is cash payment when there is a transaction between the seller, namely farmers and buyers, namely traders, industrial farmers, and small industries.

Industrial farmers processing chips get raw material stock not only from their own agricultural products, but also through pure farmers and traders. Generally, the purchase of cassava as a raw material is done when the stock of raw materials from the field is not enough to meet the production target. Cassava raw material

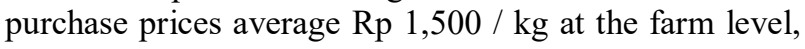

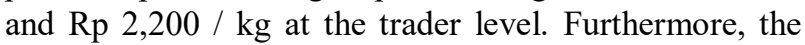


results of the production of chips are packaged in small plastic wrap and sell for Rp1,000 / pack, which is marketed to small kiosks. Average price of IDR 19,000 / $\mathrm{kg}$ with a profit margin of $30 \% / \mathrm{kg}$.

Industrial farmers who process cassava into tape have a longer cropping pattern. Cassava planting and harvesting is done during the rainy season of Ramadan because tape production is carried out in that month. The demand for cassava tape during Ramadan and Eid al-Fitr has increased significantly. Sales of cassava tape production in collaboration with central souvenir stalls of Jember Regency. The selling price of cassava tape is Rp.8000 / pack with an average weight of 7ons / pack. The added value obtained is quite large when compared to the price of cassava / $\mathrm{kg}$ at the farm level. However, although the demand for tape increased during the month of Ramadan and Eid al-Fitr, there were also problems that were experienced by the tape industry farmers, namely the level of tape durability that was only briefly so that the losses of the tape industry farmers occurred when returning the tape by the central souvenir stalls.

According to respondents, the amount of tape demand was also offset by tape production and the inclusion of tape from other districts, especially Bondowoso as the largest tape producer. One respondent of the tape industry farmer said that in Ramadan in 2017, the profit earned from tape sales was only around Rp. 2,000,000 for an area of $0.25 \mathrm{Ha}$. The small profit earned is due to the return of the tape because it was not sold until the expiration date.

Traders are specifically divided into two, namely middlemen and retailers, but in this study both are grouped into one economic agent group, namely as traders. Traders are raw cassava buyers from pure farmers and as cassava sellers in industry and markets. Traders act as distributors of cassava to economic players in the cassava market. Traders supply cassava from farmers not only in Jember, but in the surrounding districts. Cassava prices move according to the quantity of cassava stock in the market. If the amount of cassava decreases or the demand for processed cassava products increases in price, the price of cassava will increase to a range of Rp. 2,000-2500/ kg. But if the opposite happens, then the price of cassava at the farm level will decrease even up to $\mathrm{Rp} 700 / \mathrm{kg}$ so that farmers experience a loss at that price level. Traders then sell unprocessed cassava to the final market, small industries or to industrial farmers.

Small industry is a processing industry with a number of employees of less than 20 people. A small industry in Jember Regency is a cooperative business that produces Mocaf chips to be sold to large factories that produce mocaf flour. The cooperative cooperates with local farmers in the form of partnerships, and the cooperative becomes a distributor of cassava seeds and also a sole buyer of cassava from farmers who are partners. The main objective of forming a cooperative is to increase farmers' awareness of the economic value of cassava, as well as improve the welfare of the lives of farmers who partner with cooperatives. In addition to the welfare of farmers, the existence of a mocaf chip manufacturer can also open new jobs that can accommodate workers from around the factory site. The problem that arises is the price of cassava price fluctuations that cause the price of mocaf chips is also affected.

Farmers generally sell directly to traders, industrial farmers, and small industries without the expense of marketing success. Farmers as respondents explained that there were no other costs that were not directly related to cassava transactions. In addition, farmers also have no problems in accessing information related to the price of cassava on the market. The ease of accessing this information can be pointed out as one of the factors that negates transaction costs at the farm level.

Traders are basically economic agents who are able to access price information as much as possible. Traders can access price information on the availability of raw materials from farmers and industry to end consumers. Thus, the trader is able to minimize transaction costs up to zero rupiah. At the small industry level there are also no transaction costs in the form of product marketing and information accessibility. The marketing and distribution of cassava derivative products do not require additional costs that can be categorized as transaction costs. The same thing is felt by industrial farmers when they need cassava raw materials from pure farmers because of their limited cassava stock. The tape and chips industry has information on raw material prices from farmers and cassava middlemen. The output price is also determined based on price information from retailers

Another institutional phenomenon obtained during the interview was the existence of social capital. Social capital is one of the concepts in the framework of institutional economic thinking. Fukuyama (1995) defines social capital as a capability that arises because of a general belief in a society or parts of the community itself. He also added that social capital is inseparable from the values and norms that exist that make cooperation possible. Social capital in this study was studied to be able to know the carrying capacity of the community as a social entity. Cassava trading chain from upstream, namely farmers as cassava producers which are raw materials to downstream, namely consumers as end users of various processed cassava products. Social capital is one phenomenon that can have a good impact on the cassava trading chain.

At the farmer level, social capital is one of the strengths for the sustainability of cassava marketing [11]. The social capital is in the form of a guarantee for the certainty of selling crops by buyers who already have a cooperative relationship. In Jember Regency, there is a cooperative relationship between traders and small industries. The mocaf and tape chip industry as a cassava buyer at the farm level can help farmers obtain certainty in the distribution of their cassava crops. The cooperative relationship between the mocaf chip industry and the cassava farmers is in the form of a partnership, where there is a certainty the price of cassava per $\mathrm{kg}$ so that it can benefit farmers. In addition, the industry also provides support in the form of free cassava seeds to farmers suitable for mocaf chip production. The benefit received by the mocaf industry is the guarantee of the 
availability of raw materials from farmers. In the tape industry, farmers also get social capital in the form of cooperation to market their cassava to the industry every harvest. At the middleman level, social capital is formed due to the intensive distribution of cassava from farmers to industry and directly to the final market. Intensive trade ultimately produces social capital that is useful for middlemen. middlemen obtain certainty of raw material stock from farmers, and get certain quantity of cassava sales to industry in a certain quantity continuously.

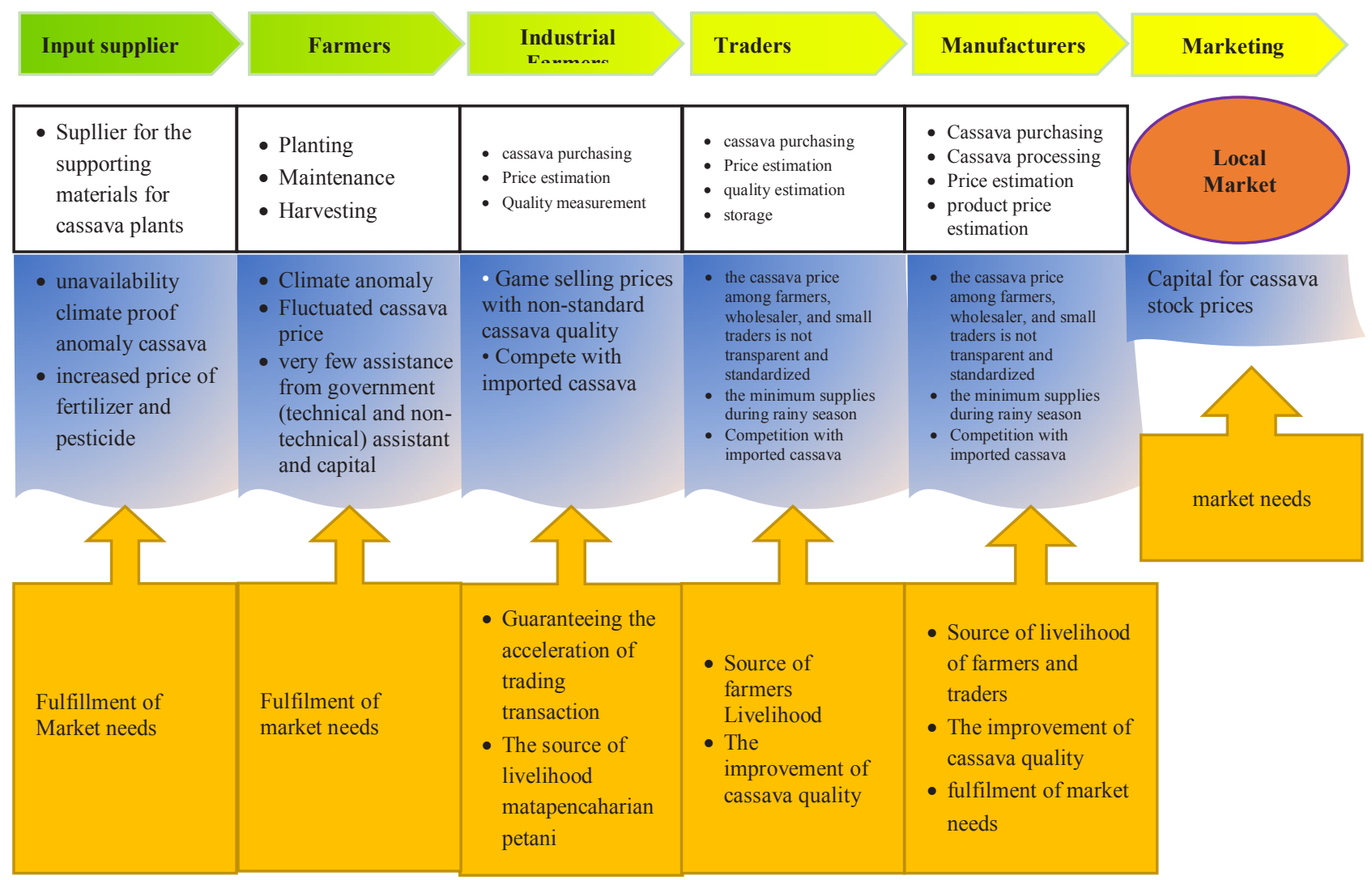

Figure 1. Scheme of Value Chain of Cassava supplies in Jember (Source: Primary Data, processed, 2018)

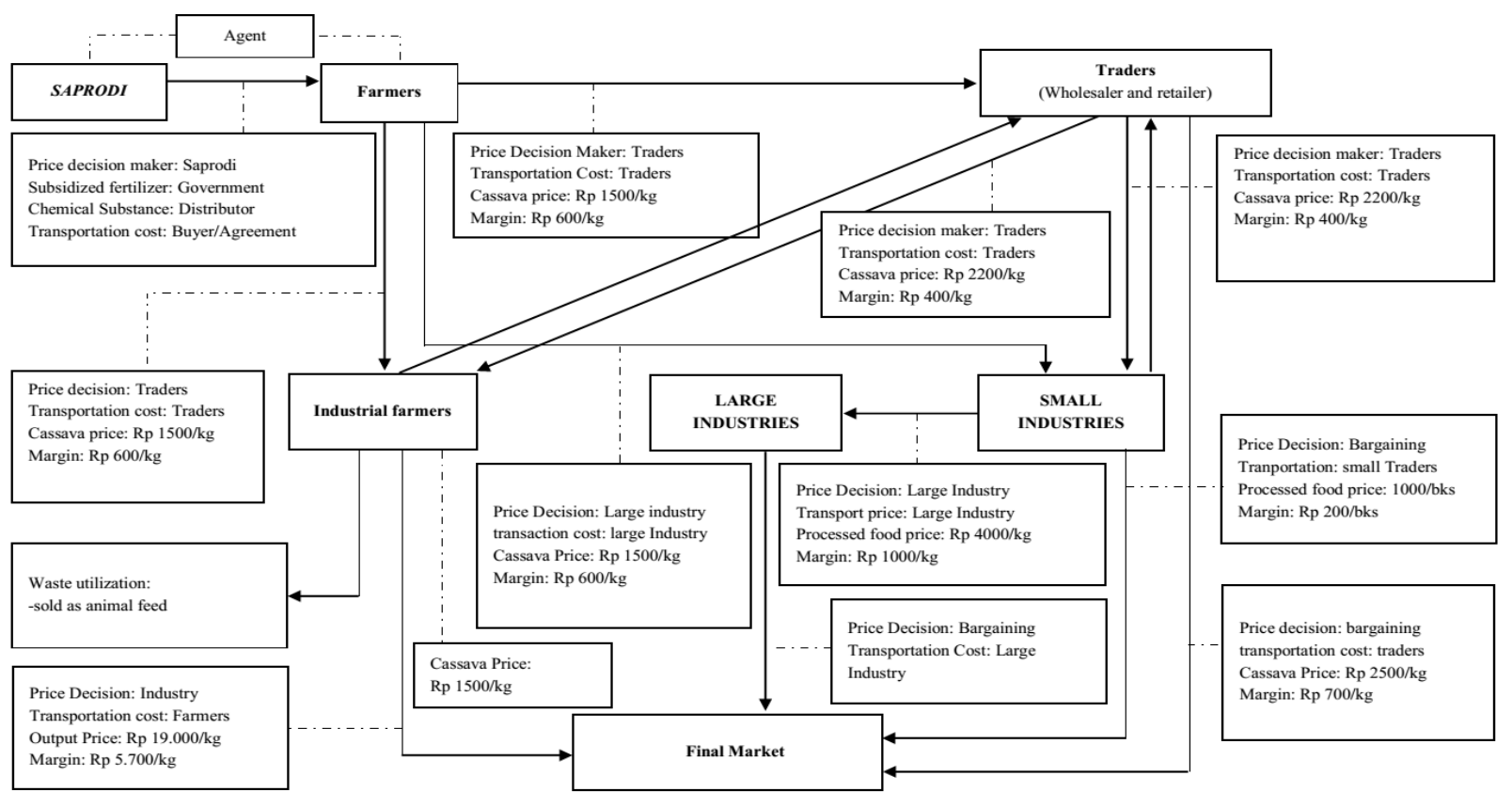

Figure 2 Value Chain of Cassava Commodities Market of Jember Regency (Source: Primary Data, processed, 2018) 


\section{CONCLUSION}

Another institutional phenomenon obtained during the interview was the existence of social capital. Social capital is one of the concepts in the framework of institutional economic thinking. Fukuyama (1995) on [2] defines social capital as a capability that arises because of a general belief in a society or parts of the community itself. He also added that social capital is inseparable from the values and norms that exist that make cooperation possible. Social capital in this study was studied to be able to know the carrying capacity of the community as a social entity. Cassava trading chain from upstream, namely farmers as cassava producers which are raw materials to downstream, namely consumers as end users of various processed cassava products. Social capital is one phenomenon that can have a good impact on the cassava trading chain.

At the farmer level, social capital is one of the strengths for the sustainability of cassava marketing $[3][12][15]$. The social capital is in the form of a guarantee for the certainty of selling crops by buyers who already have a cooperative relationship. In Jember Regency, there is a cooperative relationship between traders and small industries. The mocaf and tape chip industry as a cassava buyer at the farm level can help farmers obtain certainty in the distribution of their cassava crops. The cooperative relationship between the mocaf chip industry and the cassava farmers is in the form of a partnership, where there is a certainty the price of cassava per $\mathrm{kg}$ so that it can benefit farmers. In addition, the industry also provides support in the form of free cassava seeds to farmers suitable for mocaf chip production. The benefit received by the mocaf industry is the guarantee of the availability of raw materials from farmers. In the tape industry, farmers also get social capital in the form of cooperation to market their cassava to the industry every harvest. At the middleman level, social capital is formed due to the intensive distribution of cassava from farmers to industry and directly to the final market. Intensive trade ultimately produces social capital that is useful for middlemen. middlemen obtain certainty of raw material stock from farmers, and get certain quantity of cassava sales to industry in a certain quantity continuously.

Social capital is also built at the level of small cassava processing industries. the urgency of the certainty of the amount of raw materials and the sale of semi-finished and finished products has made the industry do a way to build social capital both with cassava farmers and buyers of their processed products. Cooperation between industry and farmers has been mentioned previously, namely in the form of partnerships or not in the form of partnerships which ultimately lead to the availability of raw materials and price stability to support the sustainability of the industrial business.
Based on the results of the analysis it was found that the largest transaction costs were at the level of traders and industry. At the farmer level, social capital is one of the strengths for cassava marketing sustainability. The social capital is in the form of guarantees for the certainty of the sale of crops by buyers who already have a cooperative relationship. The policy recommendations that can be given are the optimization of the role of farmer groups for the sustainability of cassava production and the implementation of cassava-based processed product development programs and the provision of marketing. The policy recommendations that can be given are as follows: (1) maximizing the role of farmer groups and the community for the sustainability of cassava production; (2) Stabilization of cassava prices at the farm level and the supply of cassava farming needs so that it can maintain the quantity of cassava production; (3) cassava-based product development program and marketing provision.

\section{REFERENCES}

[1] Okorie, Oguejiofor Joseph. 2012. Level of Adoption of Improved Cassava Varieties And The Profitability of Cassava Production In Enugu State, Nigeria. Disertation: Department of Agricultural Economics University of Nigeria, Nsukka

[2] Pingmuanglek, P., Jakrawatana, N., dan Gheewala, S. H. 2017. Supply Chain Analysis for Cassava Starch Production: Cleaner Production Opportunities and Benefits. Journal of Cleaner Production, Vol. 162, Hal. 1075-1084.

[3] NigeL, K., E. Sadoulet and A. De Janvry. 2000. Transaction costs and agricultural household supply response. American Journal Agricultural Economics 82(2): 245 - 259.

[4] Tanuwijaya, Fanny. 2013. Kebijakan Pengelolaan Tanaman Singkong dalam Meningkatkan Kesejahteraan Petani Singkong di Kabupaten Jember. Jember: Universitas Jember.

[5] Badan Pusat Statistik. 2017. Jember Dalam Angka.

[6] Bardhan P. 1989. Alternative Approaches to the Theory of Institutional in Economic Development. In Pranab Bardhan. (ed). The Economic Theory of Agrarian Institutions. Oxpord : Clarendon Press

[7] Madhin, G. Z. E. 1999. Transaction Costs and Market. Institutions Grain Brokers in Ethiopia. MSSD Discussion Paper No 31. International Food Policy Research.

[8] Bardhan, Pranab. 1993. Economic of Development and the Development of Economic. Journal of Economic Perspectives, Vol. 7 No. 2, Hal. 129-142.

[9] Dutilly-Diane, C., E. Sadoulet and A. de Janvry. 2003. Household Behavior Under Market Failures: How Natural Resource Management in Promotes Livestock Production in the Sahel. Department of 
Agricultural and Resource Economics. University of California, Berkeley.

[10] Minot, N. 1999. Effect of Transaction Cost on Supply Respone and Marketed Surplus : Simulations Using Non-Separable Household Model. Internatioal Food Policy Researh Institute Washington, D.C.

[11] Coase, R. H. 1960. The Problem of Social Cost. Journal of Law and Economics, Vol. 3, Hal. 1-44.

[12] North D.C. 1990. Institutions, Institutional change and Economic Performance. Cambridge : Cambridge University Press

[13] Schultz, T. W. 1963. Investment in Human Capital. American Economic Review, Vol. 51, Hal. 1-16.

[14] Amarender, Reddy A. (2013) Training Manual on Value Chain Analysis of Dryland Agricultural Commodities. International Crops Research Institute for the Semi-Arid Tropics (ICRISAT), p.4.

[15] Becker, Gary. 1962. Investment in Human Capital: A Theoretical Analysis. Journal of Political Economy, Vol. 70, Hal. 9-49. 